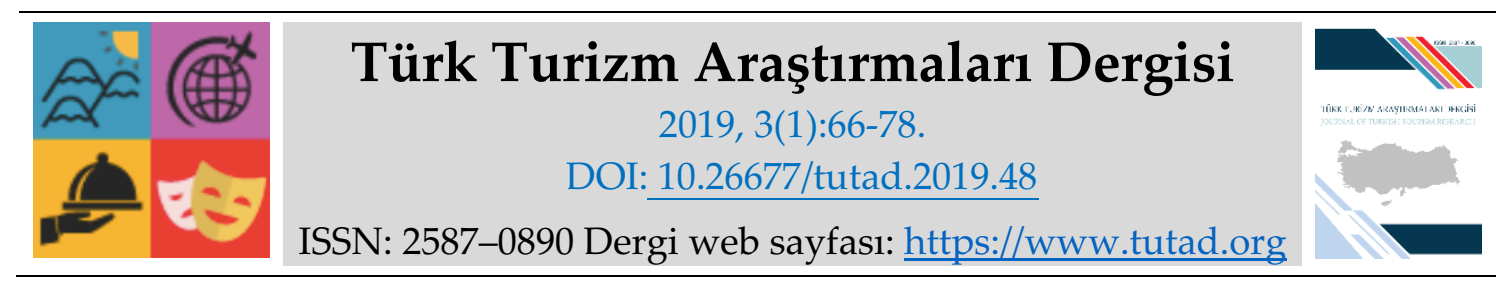

ARAŞTIRMA MAKALESI

\title{
Restoran Müşterilerinin Personel İletişim Düzeyi Algıları ve Memnuniyetleri Arasındaki İlişki*
}

\section{Dr. Öğr. Üyesi Ozan BÜYÜKYILMAZ}

Karabük Üniversitesi, İşletme Fakültesi, İşletme Bölümü, Karabük

e-posta: ozanbuyukyilmaz@karabuk.edu.tr

ORCID: https://orcid.org/0000-0001-5499-1485

Ömer Ceyhun APAK

Karabük Üniversitesi, Sosyal Bilimler Enstitüsü, İşletme ABD, Karabük

e-posta: ceyhun.apak@hotmail.com

ORCID: https://orcid.org/0000-0002-1409-6707

Öz

Yiyecek-içecek hizmeti sunan restoranlar için en önemli konu müşterilerin memnun edilmesidir. Restoranların fiziki koşulları istek ve ihtiyacını karşılamayı amaçlayan müşteriler için önemlidir. Bununla birlikte, restoranların emek yoğun hizmet işletmeleri olması sebebiyle, doğrudan iletişim kurulan personel davranışlarının da müşteri memnuniyetinin oluşmasında payı vardır. Bu bağlamda çalışmanın amacı personel iletişim düzeyinin müşteri memnuniyeti üzerindeki etkisini belirleyebilmektir. Belirlenen amaç doğrultusunda Safranbolu'daki restoranları ziyaret eden 427 müşteriye anket uygulanarak personel iletişim düzeyi algıları ve memnuniyetleri incelenmiştir. Elde edilen bulgular, müşteri memnuniyeti üzerinde iletişimin önemli bir etkisinin bulunduğunu göstermektedir.

Anahtar Kelimeler: Personel İletişim Düzeyi, Müşteri Memnuniyeti, Safranbolu.

Makale Gönderme Tarihi: 01.10.2018

Makale Kabul Tarihi: 23.12.2018

\section{Önerilen Atıf:}

Büyükyılmaz, O ve Apak, Ö. C (2019). Restoran Müşterilerinin Personel İletişim Düzeyi Algıları ve Memnuniyetleri Arasındaki İlişki, Türk Turizm Araştırmaları Dergisi, 3(1):66-78.

(c) 2019 Türk Turizm Araştırmaları Dergisi.

\footnotetext{
* Bu çalışma, 4. Uluslararası Türk Dünyası Turizm Sempozyumu (19-21 Temmuz 2018) kapsamında bildiri olarak sunulmuştur.
} 


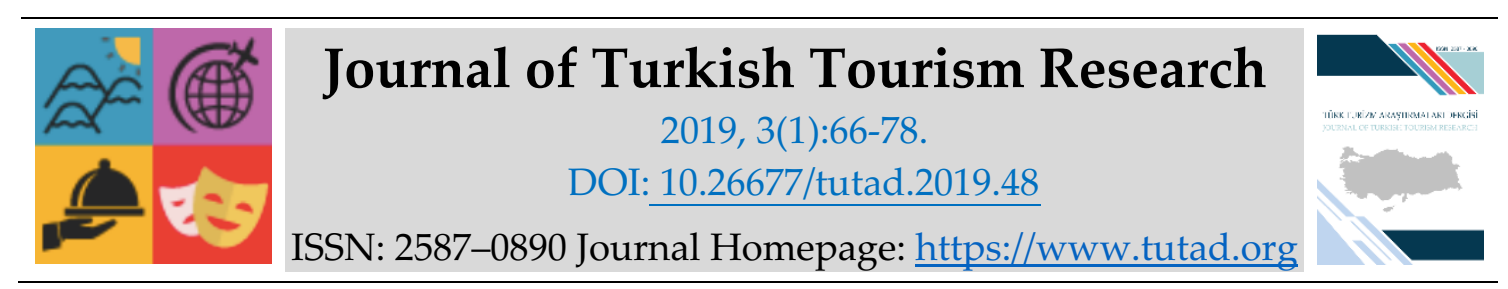

\title{
$\underline{\text { RESEARCH PAPER }}$
}

\section{The Relationship Between Restaurant Customers' Perceptions of Personnel Communication Level and Satisfaction}

\author{
Asst. Prof. Dr. Ozan BÜYÜKYILMAZ \\ Karabük University, Faculty of Business, Department of Business Administration, Karabük \\ e-mail: ozanbuyukyilmaz@karabuk.edu.tr \\ ORCID: https://orcid.org/0000-0001-5499-1485
}

Ömer Ceyhun APAK

Karabük University, Social Sciences Institute, Karabük

e-mail: ceyhun.apak@hotmail.com

ORCID: https://orcid.org/0000-0002-1409-6707

\begin{abstract}
The most important issue for restaurants offering food and beverage services is satisfaction of the customers. The physical conditions of restaurants are important for customers who want to meet their needs and desires. However, due to the fact that restaurants are labor-intensive service establishments, the behavior of employees who communicate directly with the customers also contributes to the formation of customer satisfaction. In this context, the aim of this study is to determine the effect of employees' communication level on customer satisfaction. In accordance with this purpose, a survey was conducted to assess the perceptions of employee communication level and customer satisfaction level on 427 customers who visited restaurants in Safranbolu. The findings show that there is a significant effect of communication on customer satisfaction.
\end{abstract}

Keywords: Employee Communication Level, Customer Satisfaction, Safranbolu.

Received: 01.10 .2018

Accepted: 23.12.2018

\section{Suggested Citation:}

Büyükyllmaz, O and Apak, Ö. C (2019). The Relationship Between Restaurant Customers' Perceptions of Personnel Communication Level and Satisfaction, Journal of Turkish Tourism Research, 3(1):66-78.

(C) 2019 Türk Turizm Araştırmaları Dergisi. 


\section{Gíriş}

Globalleşme eğilimleri ve sanayileşmenin hızla artması tüm sektörler açısından rekabet ortamının oluşmasına yol açmıştır. Rekabetin oluşması çeşitli sektörlerde olduğu gibi yiyecekiçecek sektörünü de önemli ölçüde etkilemiştir (Farrell vd., 2001). Bu bağlamda yiyecek ve içecek hizmeti sunan işletmelerin varlığını sürdürmesi, kaliteli ürün ve hizmetler sunarak gerçekleşmektedir. Hizmet işletmelerini farklı kılan özelliği rakip işletmelere göre sunduğu hizmetlerin daha kaliteli olmasıdır. Müşteri memnuniyetini sağlamak için yiyecek içecek işletmelerindeki atmosfer, yiyecek ve içecekler için kullanılan ekipmanlar ve işletmenin çekiciliği önemlidir. Bunun yanında bu hizmetlerin sunumunda insan faktörü göz ardı edilmemelidir. Ürün veya hizmetlerin sunumunda müşteri tatmininin sağlanmasında çalışan personelin davranışları ve müşterilerle olan iletişimleri müşteri sadakatinin oluşmasına olanak sağlamaktadır (Olcay vd., 2014; Bucak ve Turan, 2016).

İşletmelerde ürün ve hizmetlerin sunulması aşamasında, personel arasındaki iletişimin yeterli olması hizmet sunumunu kolaylaştırırken iletişimde yetersizlik olması halinde hizmet sunumunda aksaklıkları meydana getirmektedir. Dolayısıyla müşteri memnuniyetsizliğinin yaşanması kaçınılmaz olmaktadır. İşletmelerde personeller arasındaki iletişimin öneminin yanında ürün ve hizmetlerin sunumunda müşteriler ve personeller arasındaki iletişim de önemlidir. Çalışan personelin hizmet sunarken sürekli iletişim halinde olduğu müşterilerin memnun kalmasına çeşitli iletişim becerileriyle etki etmektedir (Çıkmaz, 2013).

$\mathrm{Bu}$ araştırmanın amacı, ziyaretçilerin yiyecek içecek işletmelerinde çalışan personelin iletişim düzeyi algıları ve memnuniyetleri üzerine bilimsel temelli bir bakış açısı geliştirmektir. Bu amaç doğrultusunda yiyecek içecek işletmelerinde ürün ve hizmet satın alan ziyaretçilerin çalışan personelin iletişim düzeyi algısı ile memnuniyet algıları arasında ilişkinin olup olmadığı analiz edilmektedir. Ayrıca araştırmada ziyaretçilerin memnuniyet düzeylerinin ölçülmesiyle turizm açısından önemli bir varış noktası olan Safranbolu ilçesinde bulunan yiyecek ve içecek işletmelerine yol gösterici olması beklenmektedir.

\section{LITERATÜR TARAMASI}

Dışarıda yemek yeme alışkanlığının hızla artması yiyecek içecek işletmelerindeki sayının da artmasına neden olmuştur. Bu nedenle yiyecek içecek hizmeti sunan işletmeler arasında rekabet ortamı meydana gelmiştir. Pazarlama stratejilerini doğru şekilde uygulayan işletmeler bu şekilde daha tatminkâr müşteri portföyü elde ederek rekabet üstünlüğü avantajını elde edebileceklerdir. Kaliteli hizmet sunarak rekabet üstünlüğü sağlayan işletmeler, müşterilerin memnun kalmasını sağlamakta ve tekrar satın alma davranışlarını etkileyebilmektedirler (Quin ve Prybutok, 2009).

Yiyecek içecek işletmelerinde müşterilerin memnuniyetini sağlamak için hizmet kalitesinin yüksek olması, sunulan yiyecek ve içeceklerin kusursuz olması gerektiği vurgulanmaktadır. Gıdaların ve hizmet kalitesinin müşterilerin beklentilerini karşılaması, restorana yönelik gelecekteki müşteri davranışlarını önemli derecede etkileyecektir (Petzer ve Mackay, 2014). Müşteriler bir restorandan memnun ayrılmak için sunulan yiyecek ve içecek hizmetlerinin kaliteli olmasını beklerken bunun yanında restoranın atmosferi, ambiyansı, tasarımı, kullanılan renkler, müzik, aydınlatma gibi faktörleri de göz önünde bulundurmaktadırlar (Kumar vd., 2010).

Restoranlarda atmosfer, görsel ve duygusal olarak müşterilerin iyi hissetmelerini sağlamaktadır. Görsel olarak hoş bir şekilde tasarlanan bir işletme, insanların ruh halini olumlu şekilde etkilemektedir. İyi bir yerleşim düzenine sahip ve müşterilere kalabalık hissettirmeyecek şekilde tasarlanan işletmeler ise müşterilere rahat bir ortam sunmakta ve memnuniyet duymalarını 
sağlamaktadır. Renkler ve aydınlatmanın da restoranlar için önemi kaçınılmazdır. Renk ve aydınlatma, müşterilerin heyecan duymasına katkı sağlayarak tüketicilerin zihninde olumlu izlenimler uyanmasını sağlamaktadır. Ayrıca işletmelerde kullanılan dinlendirici müzikler, restoranı ziyaret eden müşterilerin rahatlamasına etki edecektir (Countryman ve Jang, 2006).

Fiziki koşulların (atmosfer, tasarım, renk, müzik, aydınlatma vb.) yanı sıra restoranlarda müşterilerin memnuniyetinin ve sadakatinin oluşumu çalışan personelle de ilişkilidir. Hizmet yoğun işletmelerde iletişimin odak noktası olan insan faktörü memnuniyet için belirleyici bir rol oynamaktadır. Müşteriler ve personeller arasındaki iletişimde sözlü, yazılı ve beden dili olarak ifade edilen iletişim becerileri öne çıkmakla birlikte, bu iletişimin başarıya ulaşması için işletmede çalışan personelin iyi bir iletişim becerisinin olması gerekmektedir (Erkuş ve Günlü, 2009). Bununla birlikte Olcay vd. (2014) çalışmasında, işletmelerde çalışan personellerin bireysel olarak özelliklerinin ve becerilerinin müşteriler ile etkileşim sağlamada çok önemli olduğunu vurgulamıştır. Emek yoğun olan otel, restoran vb. işletmelerde kar elde edebilmek için önemli bir faktör olan personellerin işe alım sürecinde beden dili, sözlü ve yazılı iletişim yetkinliği konusunda bazı kriterlere göre seçim yapılması gerekliliği öngörülmüş olup müşteri memnuniyetini sağlamada personelin etkili olduğuna dikkat çekilmiştir. Bununla birlikte kalite ve imajın konukların zihninde canlı tutulması için hizmet içi eğitimlerin önemli olduğu ifade edilmektedir (Ayaz ve Yalı, 2017).

\section{YÖNTEM}

Yiyecek ve içecek sektörü emek yoğun bir sektör olması sebebiyle müşterilerin memnuniyetlerinin sağlanması çok önemlidir. Bu bağlamda hem işletmelerin fiziki koşulları hem de sunulan hizmetlerin sağlanmasına kaynaklık eden personeller, konuk memnuniyetinin oluşumunu etkileyecek bir durum olarak görülebilmektedir. Dolayısıyla bu araştırma, yiyecek içecek işletmelerinde sunulan hizmetlerin yeterliliği kapsamında müşteriler perspektifinden katkı sağlanması düşüncesiyle hazırlanmış betimsel bir çalışmadır.

\section{Araştırmanın Problemi, Amacı ve Önemi}

Araştırmada yiyecek-içecek işletmelerinde çalışan personellerin iletişim düzeyinin müşteri memnuniyeti üzerine etkisinin ortaya çıkarılması amaçlanmıştır. Bu amaçla birlikte araştırma problemi "restoranlarda çalışan personellerin iletişim düzeyinin müşteri memnuniyetine olumlu bir etkisinin bulunup bulunmadığının test edilmesi" olarak öngörülmüştür. Araştırmada temel amaç, restoranlarda çalışan personellerin iletişim düzeylerinin ve müşteri memnuniyetlerinin ortaya çıkarılmasıdır. Bu kapsamda çalışmanın Safranbolu turizm destinasyonunda bulunan yiyecek-içecek işletmelerini müşteri memnuniyeti konusunda bilgilendirmesi, personelin iletişim düzeyi ve konukların memnuniyeti konusunda ilgili kurumlara bilimsel olarak katkı sağlaması beklenmektedir.

\section{Araştırmanın Modeli ve Hipotezler}

Personel iletişim düzeyinin müşteri memnuniyetine etkisinin test edilmesi amacıyla hazırlanan çalışmada araştırma modeli Şekil 1'de öngörülmüştür. 


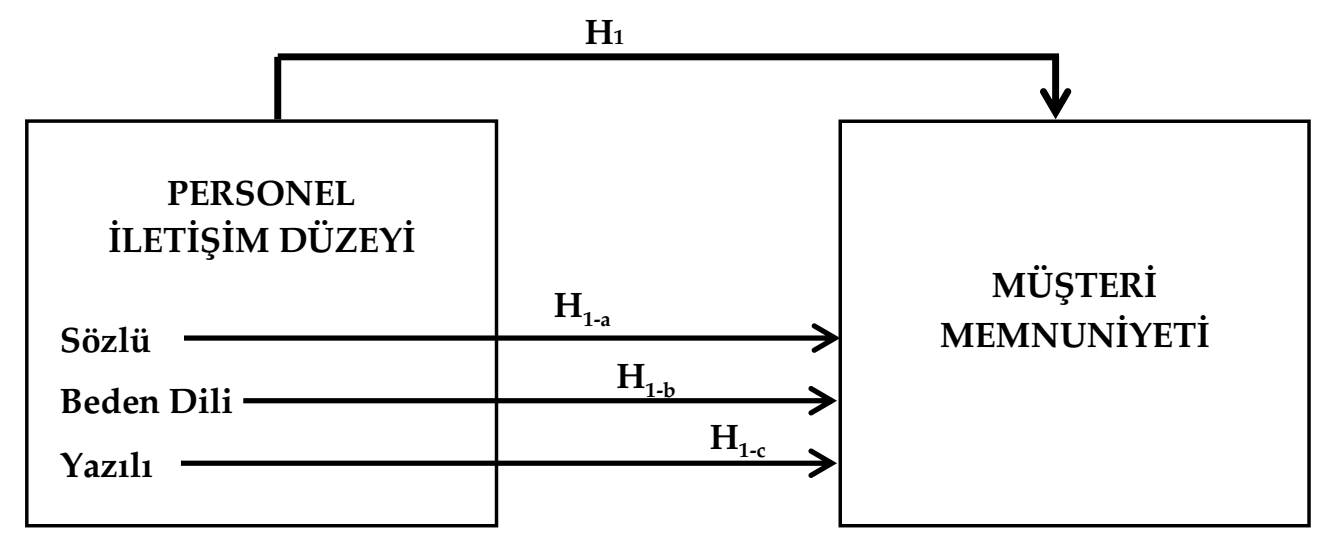

Şekil 1. Araştırma Modeli

H1: Personel iletişim düzeyinin müşteri memnuniyetine olumlu etkisi vardır.

H1-a: Personel iletişim düzeyi olarak sözlü iletişimin müşteri memnuniyetine olumlu etkisi vardir.

H1-b: Personel iletişim düzeyi olarak beden dilinin müşteri memnuniyetine olumlu etkisi vardır.

H1-c: Personel iletişim düzeyi olarak yazılı iletişimin müşteri memnuniyetine olumlu etkisi vardir.

\section{Araştırmanın Evreni ve Örneklem}

Araştırmanın evreninin, Safranbolu ilçesinde bulunan 199 yiyecek-içecek işletmesi oluşturmuştur. Bu veriler kapsamında zaman, ulaşılabilirlik ve maliyet unsurlarının dikkate alınmasıyla örnekleme başvurulmuştur. Örneklem büyüklüğü \%+-5 hata payında ve $Z$ değeri 1,96 olmak üzere 74 restoran olarak belirlenmiştir. Bu bağlamda 384 ziyaretçiye ulaşılması öngörülmüştür.

\section{Verilerin Toplanması ve Analizi}

İki aşamalı süreçte toplanan araştırma verileri kapsamında birinci aşamada literatür incelemesi olarak ikincil kaynaklardan personel iletişim düzeyi ve müşteri memnuniyetine yönelik tarama yapılmış olup ikinci aşamada ise müşterilerin personel iletişim düzeyi algılarını ve memnuniyetlerini belirlemek amacıyla anket ölçeği tasarlanmıştır. Anket ölçeğinin hazırlanması sürecinde Olcay vd. (2014) ve Ünal vd. (2014) araştırmalarından faydalanılmıştır. Kolayda örneklem yöntemi kapsamında Kasım 2017 döneminde uygulanan anketin ön testi kapsamında restoranları ziyaret eden 50 müşteri ile görüşülmüştür. Ön test verileri analizi sonuçlarına göre personel iletişim düzeyi bölümü için 7 soru memnuniyet için ise 1 soru çıkarılarak ölçek düzenlenmiştir. Düzenleme yapıldıktan sonra personel iletişimi için Cronbach Alpha değeri 0,74; memnuniyet için ise 0,81 olarak tespit edilmiştir. Anket Aralık 2017-Şubat 2018 tarihleri arasında Safranbolu'daki restoranları ziyaret eden müşterilere kolayda örneklem ve yüz yüze anket tekniği kapsamında araştırmacı tarafından doldurtulmuştur. Anketin uygulanması aşamasında 450 anket dağıtılmış ve 435 anketten geri dönüş sağlanmış (geri dönüş oranı \%95) olup kullanılabilir 427 anket ile araştırmanın uygulama kısmı gerçekleştirilmiştir. 
Araştırma için kullanılan anket üç kısımdan oluşmaktadır. İlk kısımda; restoranları ziyaret eden müşterilerin demografik özelliklerini belirlemeye yönelik kişisel bilgileri (cinsiyet, medeni durum, yaş, eğitim durumu, aylık gelir, restoran ziyaret etme sıklığı) belirlenmiştir. İkinci ve üçüncü kısımda ise restoranları ziyaret eden müşterilerin personel iletişim düzeyi algılarının ve memnuniyetlerinin belirlenmesi kapsamında aralıklı ölçek kullanılmıştır. 5'li Likert Ölçeği "1=Hiç Katılmıyorum; 2=Katılmıyorum; 3=Orta Düzeyde Katılıyorum; 4=Katılıyorum; $5=$ Tamamen Katıllyorum" şeklinde tasarlanmıştır. Toplanan verilerin analizinde ise yüzde ve frekans analizi, standart sapma, aritmetik ortalama, korelasyon ve regresyon analizi kullanılmıştır.

\section{BULGULAR}

Restoranları ziyaret eden müşterilere yönelik demografik özellikler açısından yüzde ve frekans analizi sıralanmış olup Tablo 1'de gösterilmiştir. Katılımcılara ilişkin bilgilerde cinsiyet açısından erkekler (\%55,3), medeni durum açısından bekarlar $(\% 61,6)$, eğitim durumu açısından lisans eğitimli olanlar (\%40,7), yaş açısından 21-30 yaş aralığı (\%35,8), aylık gelir açısından 1500 TL ve altı $(\% 26,7)$ ve $1501-2500$ TL $(\% 25,5)$ ve restorana gitme sıklığı açısından ise haftada birkaç kez $(\% 26,9)$ ve haftada bir kez $(30,7)$ olarak ön plana çıktığı söylenebilir.

Tablo 1. Katılımcılara İlişkin Tanımlayıcı Bilgiler $(\mathrm{n}=427)$

\begin{tabular}{|l|l|c|c|}
\hline Değiş̧enler & \multicolumn{1}{|c|}{ Gruplar } & f & \% \\
\hline \multirow{3}{*}{ Cinsiyet } & Erkek & 236 & 55,3 \\
\cline { 2 - 4 } & Kadın & 191 & 44,7 \\
\hline \multirow{4}{*}{ Eedeni Durum } & Evli & 164 & 38,4 \\
\cline { 2 - 4 } & Bekâr & 263 & 61,6 \\
\hline \multirow{5}{*}{ Yaş } & Ortaöğretim & 85 & 19,9 \\
\cline { 2 - 4 } & Ön lisans & 136 & 31,9 \\
\cline { 2 - 4 } & Lisans & 174 & 40,7 \\
\cline { 2 - 4 } & Lisansüstü & 32 & 7,5 \\
\hline \multirow{5}{*}{ Aylık Gelir } & 20 yaş ve altı & 99 & 23,2 \\
\cline { 2 - 4 } & 21-30 yaş & 153 & 35,8 \\
\cline { 2 - 4 } & 31-40 yaş & 100 & 23,4 \\
\cline { 2 - 4 } & 41 yaş ve üzeri & 75 & 17,6 \\
\hline & 1500 TL ve altı & 114 & 26,7 \\
\cline { 2 - 4 } & 1501-2500 TL & 109 & 25,5 \\
\cline { 2 - 4 } & 2501-3500 TL & 82 & 19,2 \\
\cline { 2 - 4 } & 3501-4500 TL & 67 & 15,7 \\
\cline { 2 - 4 } & 4501 TL ve üzeri & 55 & 12,9 \\
\hline \multirow{5}{*}{ Restorana Gitme Sıklığ1 } & Her gün & 52 & 12,2 \\
\cline { 2 - 4 } & Haftada birkaç kez & 115 & 26,9 \\
\cline { 2 - 4 } & Haftada bir kez & 81 & 30,7 \\
\cline { 2 - 4 } & On beş günde bir kez & 48 & 11,2 \\
\cline { 2 - 4 } & Ayda bir kez & & \\
\hline
\end{tabular}


Araştırma verilerine göre müşterilerin Safranbolu'daki restoranlarda çalışan personel iletişim düzeyi algılarına yönelik faktör analizi kapsamında üç boyut (sözlü, beden dili, yazılı) tespit edilmiştir. Boyutlara ilişkin olarak 9 yargının KMO Örneklem Ölçüm Değer Yeterliliği katsayısı 0,71, Bartlett's Kürsellik Testi anlamlılık düzeyi; $p=0,000$, varyans açılama oranı; 64,66 ve toplam güvenilirlik kat sayısı; 0,74 olarak belirlenmiş olup Tablo 2' de gösterilen biçimde sunulmuştur.

Tablo 2. Müşterilerin Personel İletişim Düzeyi Algılarına Yönelik Faktör Analizi

\begin{tabular}{|l|c|c|c|c|c|}
\hline Faktör & $\bar{X}$ & S.S & $\begin{array}{c}\text { Faktör } \\
\text { Yükü }\end{array}$ & $\begin{array}{c}\text { Cronbach } \\
\text { Alpha }\end{array}$ & $\begin{array}{c}\text { Varyans } \\
\text { Açılama } \\
(\%)\end{array}$ \\
\hline Sözlü & $\mathbf{3 , 7 6}$ & $\mathbf{0 , 7 6}$ & & $\mathbf{0 , 6 9 4}$ & $\mathbf{2 3 , 4 0 5}$ \\
\hline $\begin{array}{l}\text { Personeller kelimeleri doğru telaffuz etmekte } \\
\text { ve yöresel şive ve ağız kullanmamaya özen } \\
\text { göstermektedir. }\end{array}$ & 3,91 & 1,07 & 0,756 & & \\
\hline $\begin{array}{l}\text { Personeller konuşurken ses tonunu iyi } \\
\text { ayarlamaktadır. }\end{array}$ & 3,61 & 1,03 & 0,712 & & \\
\hline $\begin{array}{l}\text { Personeller uzun ve sıkıcı bir şekilde } \\
\text { konuşmamaktadır. }\end{array}$ & 3,92 & 0,99 & 0,706 & & \\
\hline $\begin{array}{l}\text { Personeller konuşma hızını iyi } \\
\text { ayarlamaktadır. }\end{array}$ & 3,61 & 1,09 & 0,680 & & $\mathbf{2 2 , 6 5 3}$ \\
\hline Beden Dili & $\mathbf{3 , 4 4}$ & $\mathbf{0 , 8 3}$ & & $\mathbf{0 , 7 9 5}$ & \\
\hline $\begin{array}{l}\text { Personellerin beden hareketleri abartıdan } \\
\text { uzaktır ve yapmacık değildir. }\end{array}$ & 3,48 & 0,95 & 0,861 & & $\mathbf{6 4 , 6 6 2}$ \\
\hline $\begin{array}{l}\text { Personeller el ve kollarını yerinde ve doğru } \\
\text { kullanmaktadır. }\end{array}$ & 3,51 & 0,95 & 0,859 & & \\
\hline $\begin{array}{l}\text { Personeller jest ve mimiklerini yerinde ve } \\
\text { doğru kullanmaktadır. }\end{array}$ & 3,33 & 1,14 & 0,658 & & $\mathbf{0 , 7 4 6}$ \\
\hline Yazılı & $\mathbf{3 , 6 6}$ & $\mathbf{0 , 9 3}$ & & $\mathbf{0 , 7 4 8}$ & $\mathbf{1 8 , 6 0 4}$ \\
\hline $\begin{array}{l}\text { Personeller yazılı mesajların iletiminde titiz } \\
\text { davranmaktadır. }\end{array}$ & 3,63 & 1,02 & 0,895 & & \\
\hline $\begin{array}{l}\text { Personellerin hazırladığı bilgi amaçlı yazılar } \\
\text { açık ve anlaşılırdır. }\end{array}$ & 3,68 & 1,03 & 0,874 & & \\
\hline $\begin{array}{l}\text { Toplam Cronbach Alpha / Varyans Açıklama } \\
\text { (\%) }\end{array}$ & & & & \\
\hline $\begin{array}{l}\text { KMO Örneklem Ölçüm Değer Yeterliliği: } 0,710 \\
\text { Bartlett's Kürsellik Testi (Ki-kare / sd /p (anlamlılık düzeyi): } 1030,539 / 36 / 0,000\end{array}$ & \\
\hline
\end{tabular}

Safranbolu'daki restoranları ziyaret eden müşterilerin memnuniyetlerine yönelik faktör analizi sonuçlarına göre 15 yargıya ait 5 faktör (estetik, tasarım, ambiyans, ekipman ve malzeme, aydınlatma) için KMO katsayısı 0,76, Bartlett Sphericity testi anlamlılık düzeyi; $\mathrm{p}=0,000$ olup, varyans açıklama oranı; 70,45 ve güvenirlik kat sayısı; 0,81 olarak tespit edilmiştir (Tablo 3). 
Tablo 3. Müşterilerin Memnuniyetlerine Yönelik Faktör Analizi

\begin{tabular}{|c|c|c|c|c|c|}
\hline Faktör & $\bar{X}$ & S.S & $\begin{array}{l}\text { Faktör } \\
\text { Yükü }\end{array}$ & $\begin{array}{c}\text { Cronbach } \\
\text { Alpha }\end{array}$ & \begin{tabular}{|c} 
Varyans \\
Açılama \\
$(\%)$
\end{tabular} \\
\hline Estetik & 3,35 & 0,80 & & 0,757 & 15,874 \\
\hline $\begin{array}{l}\begin{array}{l}\text { Restorandaki resimler ya da fotoğraflar ilgi } \\
\text { çekiciydi. }\end{array} \\
\end{array}$ & 3,51 & 0,95 & 0,797 & & \\
\hline $\begin{array}{|lllll|}\begin{array}{l}\text { Restorandaki } \\
\text { oluşturmuştu. }\end{array} & \text { renkler sıcak bir atmosfer } \\
\end{array}$ & 3,48 & 0,95 & 0,763 & & \\
\hline $\begin{array}{l}\text { Restorandaki duvar dekorları görsel olarak ilgi } \\
\text { çekiciydi. }\end{array}$ & 3,33 & 1,14 & 0,737 & & \\
\hline $\begin{array}{l}\text { Restorandaki bitkiler ya da çiçekler bana huzur } \\
\text { verdi. }\end{array}$ & 3,06 & 1,15 & 0,676 & & \\
\hline Tasarım & 3,79 & 0,92 & & 0,826 & 14,953 \\
\hline $\begin{array}{l}\text { Restorandaki oturma düzeni rahatça yerleşmemi } \\
\text { sağladı. }\end{array}$ & 3,82 & 1,07 & 0,867 & & \\
\hline $\begin{array}{l}\text { Restoranın yerleşim düzeni rahatça hareket } \\
\text { etmemi kolaylaştırdı. }\end{array}$ & 3,81 & 1,08 & 0,857 & & \\
\hline Restoranda çalan fon müziği beni rahatlattı. & 3,74 & 1,06 & 0,805 & & \\
\hline Ambiyans & 3,64 & 0,85 & & 0,807 & 14,477 \\
\hline Restoranın sıcaklık düzeyi uygun seviyedeydi. & 3,68 & 0,97 & 0,873 & & \\
\hline Restoranın haz verici bir kokusu vardı. & 3,64 & 1,03 & 0,821 & & \\
\hline $\begin{array}{l}\text { Restoran aydınlatması iyi bir şekilde karşılanma } \\
\text { hissi verdi. }\end{array}$ & 3,60 & 1,02 & 0,741 & & \\
\hline Ekipman ve Malzeme & 3,83 & 0,85 & & 0,783 & 14,108 \\
\hline $\begin{array}{l}\text { Restorandaki yemek takımları (çatal, bıçak gibi) } \\
\text { görsel olarak ilgi çekiciydi. }\end{array}$ & 3,89 & 1,00 & 0,863 & & \\
\hline $\begin{array}{l}\text { Restorandaki sofra örtüleri (masa örtüsü, peçete } \\
\text { gibi) ilgi çekiciydi. }\end{array}$ & 3,82 & 1,02 & 0,783 & & \\
\hline $\begin{array}{l}\text { Restorandaki sofra takımları (cam, porselen, } \\
\text { gümüș gibi) yüksek kaliteydi. }\end{array}$ & 3,79 & 1,03 & 0,768 & & \\
\hline Aydınlatma & 3,77 & 0,97 & & 0,768 & 11,047 \\
\hline $\begin{array}{|llll|}\begin{array}{l}\text { Restoran aydınlatması sicak bir atmosfer } \\
\text { yaratmıştı. }\end{array} & & & \\
\end{array}$ & 3,78 & 1,07 & 0,886 & & \\
\hline \begin{tabular}{|l} 
Restoran aydınlatması rahat bir atmosfer \\
yaratmıştı.
\end{tabular} & 3,76 & 1,08 & 0,878 & & \\
\hline $\begin{array}{l}\text { Toplam Cronbach's Alpha / Varyans Açıklama } \\
(\%)\end{array}$ & & & & & 70,459 \\
\hline
\end{tabular}

Safranbolu'daki restoranları ziyaret eden müşterilerin personel iletişim düzeyi algıları ve memnuniyetleri arasında ilişkinin bulunup bulunmadığını tespit etmek amacıyla Korelasyon Analizi öngörülmüştür. 
Tablo 4. Müşterilerin Personel İletişim Düzeyi Algıları ve Memnuniyetlerine İlişkin Korelasyon Analizi

\begin{tabular}{|c|c|c|c|c|c|c|c|c|c|c|c|}
\hline (Boyutlar-Fal & törler) & $\begin{array}{l}: \frac{7}{N} \\
: 0 \\
\text { के }\end{array}$ & 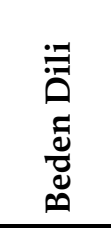 & $\begin{array}{l}\overline{\text { స్}} \\
\text { స्र }\end{array}$ & 莬 & 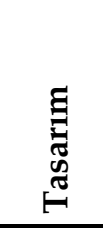 & 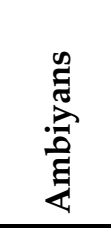 & 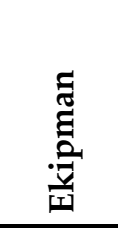 & 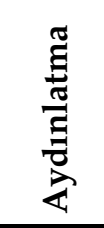 & 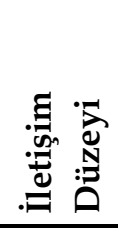 & 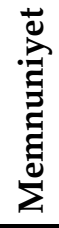 \\
\hline \multirow{2}{*}{ Sözlü } & $\mathrm{r}$ & 1 & & & & & & & & & \\
\hline & $p$ & & & & & & & & & & \\
\hline \multirow{2}{*}{ Beden Dili } & $\mathrm{r}$ & 0,252 & 1 & & & & & & & & \\
\hline & $\mathrm{p}$ & $0,000^{*}$ & & & & & & & & & \\
\hline \multirow{2}{*}{ Yazılı } & $\mathrm{r}$ & 0,194 & 0,391 & 1 & & & & & & & \\
\hline & $p$ & $0,000^{*}$ & $0,000^{*}$ & & & & & & & & \\
\hline \multirow{2}{*}{ Estetik } & $\mathrm{r}$ & 0,275 & 0,949 & 0,380 & 1 & & & & & & \\
\hline & $p$ & $0,000^{*}$ & $0,000^{*}$ & $0,000^{*}$ & & & & & & & \\
\hline \multirow{2}{*}{ Tasarım } & $\mathrm{r}$ & 0,158 & 0,224 & 0,329 & 0,224 & 1 & & & & & \\
\hline & $p$ & $0,000^{*}$ & $0,000^{*}$ & $0,000^{*}$ & $0,000^{*}$ & & & & & & \\
\hline \multirow{2}{*}{ Ambiyans } & $\mathrm{r}$ & 0,193 & 0,361 & 0,240 & 0,370 & 0,235 & 1 & & & & \\
\hline & $p$ & $0,000^{*}$ & $0,000^{*}$ & $0,000^{*}$ & $0,000^{*}$ & $0,000^{*}$ & & & & & \\
\hline \multirow{2}{*}{ Ekipman } & $\mathrm{r}$ & 0,199 & 0,320 & 0,383 & 0,306 & 0,312 & 0,362 & 1 & & & \\
\hline & $p$ & $0,000^{*}$ & $0,000^{*}$ & $0,000^{*}$ & $0,000^{*}$ & $0,000^{*}$ & $0,000^{*}$ & & & & \\
\hline \multirow{2}{*}{ Aydınlatma } & $\mathrm{r}$ & 0,250 & 0,131 & 0,241 & 0,165 & 0,137 & 0,235 & 0,128 & 1 & & \\
\hline & $p$ & $0,000^{*}$ & $0,000^{*}$ & $0,000^{*}$ & $0,000^{*}$ & $0,000^{*}$ & $0,000^{*}$ & $0,000^{*}$ & & & \\
\hline \multirow{2}{*}{$\begin{array}{l}\text { İletişim } \\
\text { Düzeyi }\end{array}$} & $\mathrm{r}$ & 0,753 & 0,748 & 0,642 & 0,731 & 0,309 & 0,362 & 0,396 & 0,287 & 1 & \\
\hline & $p$ & $0,000^{*}$ & $0,000^{*}$ & $0,000^{*}$ & $0,000^{*}$ & $0,000^{*}$ & $0,000^{*}$ & $0,000^{*}$ & $0,000^{*}$ & & \\
\hline \multirow{2}{*}{ Memnuniyet } & $\mathrm{r}$ & 0,337 & 0,679 & 0,503 & 0,705 & 0,618 & 0,694 & 0,669 & 0,453 & 0,683 & 1 \\
\hline & $p$ & $0,000^{*}$ & $0,000^{*}$ & $0,000^{*}$ & $0,000^{*}$ & $0,000^{*}$ & $0,000^{*}$ & $0,000^{*}$ & $0,000^{*}$ & $0,000^{*}$ & \\
\hline
\end{tabular}

${ }^{*}(\mathrm{p}<0,001)$

Değişkenler arası bağlılık veya ilişkinin durumunu ölçmede kullanılan korelasyon analizi, bu değişkenler arasındaki ilişkinin gücünü ve yönünü belirtmektedir. Değişkenler arasında " $r$ " değerinin 0,00-0,29 olması; "düşük" ilişkinin olduğunu, 0,30-0,69 olması; "orta" düzeyde ilişkinin olduğunu, 0,70 ve üzeri olması ise "yüksek" düzeyde ilişkinin olduğu yönünde açıklanmaktadır (Ural ve Kılıç, 2006).

Korelasyon analizi sonuçlarına göre Safranbolu'daki restoranları ziyaret eden müşterilerin personel iletişim düzeyi algıları ve memnuniyetleri arasında orta düzeyde pozitif yönlü anlamlı bir ilişki $(\mathrm{r}=0,683)$ bulunduğu görülmektedir. Bununla birlikte sözlü iletişim ile memnuniyet arasında anlamlı ilişkinin $(\mathrm{r}=0,337)$ bulunduğu saptanmıştır. Beden dili iletişimi ile memnuniyet arasında ise pozitif yönde anlamlı ilişki $(\mathrm{r}=0,679)$ olduğu tespit edilmiştir. Son olarak yazılı iletişim ile memnuniyet arasında anlamlı ilişki $(\mathrm{r}=0,503)$ olduğu görülmektedir.

Araştırma kapsamında korelasyon analizinin neden-sonuç bağlamında yorumlanabilmesi için müşterilerin personel iletişim düzeyi algıları ve memnuniyetleri alt boyutları arasındaki ilişkinin açıklanmasında çoklu doğrusal regresyon analizi ve müşterilerin personel iletişim düzeyi algıları ve memnuniyetleri arasındaki ilişkinin açıklanmasında basit doğrusal regresyon analizi Tablo 5 ve Tablo $6^{\prime}$ da gösterilmektedir. 
Tablo 5. Müşterilerin Personel İletişim Düzeyi Algıları İle Memnuniyetleri Arasındaki İlişkiye Ait Çoklu Regresyon Analizi

\begin{tabular}{|c|c|c|c|c|c|c|}
\hline $\begin{array}{l}\text { Bağımlı } \\
\text { Değişken }\end{array}$ & $\begin{array}{l}\text { Bağımsız } \\
\text { Değişken }\end{array}$ & $(\beta)$ & $\mathbf{t}$ & p & $\mathbf{F}$ & $\mathbf{R}^{2}$ \\
\hline \multirow{4}{*}{ Memnuniyet } & Sabit & 1,433 & 12,659 & $0,000^{*}$ & \multirow{4}{*}{$170,758^{*}$} & \multirow{4}{*}{0,548} \\
\hline & Sözlü & 0,109 & 4,356 & $0,000^{*}$ & & \\
\hline & Beden Dili & 0,359 & 14,845 & $0,000^{*}$ & & \\
\hline & Yazilı & 0,156 & 7,377 & $0,000^{*}$ & & \\
\hline
\end{tabular}

$*(p<0,01)$

Tablo 5 'teki bulgulara göre personel iletişim düzeylerinin, memnuniyet üzerindeki etkisine ait çok değişkenli doğrusal regresyon modeli anlamlı $(\mathrm{F}=170,758 ; \mathrm{p}<0,01)$ bulunmuştur. Katsayılardaki anlamlılık derecelerine bakıldığında; sözlü iletişim düzeyinin, beden dili iletişim düzeyinin ve yazılı iletişim düzeyinin öngörülen model üzerinde önemli bir etkiye sahip olduğu tespit edilmiştir. Katsayılara göre sözlü beden dili ve yazılı iletişim düzeylerinin memnuniyet üzerinde pozitif bir etkisi olduğu saptanmıştır. Bu doğrultuda memnuniyetteki değişimlerin, \%54 (R2=0,548) oranında sözlü, beden dili ve yazılı iletişimden kaynaklandığ1 söylenebilir. Dolayısıyla araştırmada öngörülen hipotezler (H1-a: Personel iletişim düzeyi olarak sözlü iletişimin müşteri memnuniyetine olumlu etkisi vardır. H1-b: Personel iletişim düzeyi olarak beden dilinin müşteri memnuniyetine olumlu etkisi vardır. H1-c: Personel iletişim düzeyi olarak yazılı iletişimin müşteri memnuniyetine olumlu etkisi vardır.) bulgular değerlendirilerek kabul edilmiştir.

Tablo 6. Müşterilerin Personel İletişim Düzeyi Algıları İle Memnuniyetleri Arasındaki İlişkiye Ait Basit Doğrusal Regresyon Analizi

\begin{tabular}{llccccc}
\hline Bağımlı Değişken & $\begin{array}{l}\text { Bağımsız } \\
\text { Değişkenler }\end{array}$ & $\mathbf{( \beta )}$ & $\mathbf{t}$ & $\mathbf{p}$ & $\mathbf{F}$ & $\mathbf{R}^{\mathbf{2}}$ \\
\hline Memnuniyet & İletişim Düzeyi & 0,638 & 19,288 & $\mathbf{0 , 0 0 0}$ & 372,008 & 0,467 \\
\hline
\end{tabular}

${ }^{*}(\mathrm{p}<0,01)$

Tablo 6'daki bulgulara göre personel iletişim düzeylerinin, memnuniyet üzerindeki etkisine ait basit doğrusal regresyon modeli anlamlı $(\mathrm{F}=372,008 ; \mathrm{p}<0,01)$ bulunmuştur. Bu bağlamda personel iletişim düzeyinin memnuniyet üzerinde pozitif yönlü olumlu bir etkiye sahip olduğu gözlemlenmiştir. Buna göre memnuniyetteki değişimlerde, personel iletişim düzeyinin \%46 $(\mathrm{R} 2=0,467)$ oranında etken olduğu söylenebilir. Gözlemlenen araştırma verileri doğrultusunda araştırmanın ana hipotezi (H1: Personel iletişim düzeyinin müşteri memnuniyetine olumlu etkisi vardır) kabul edilmiştir. 


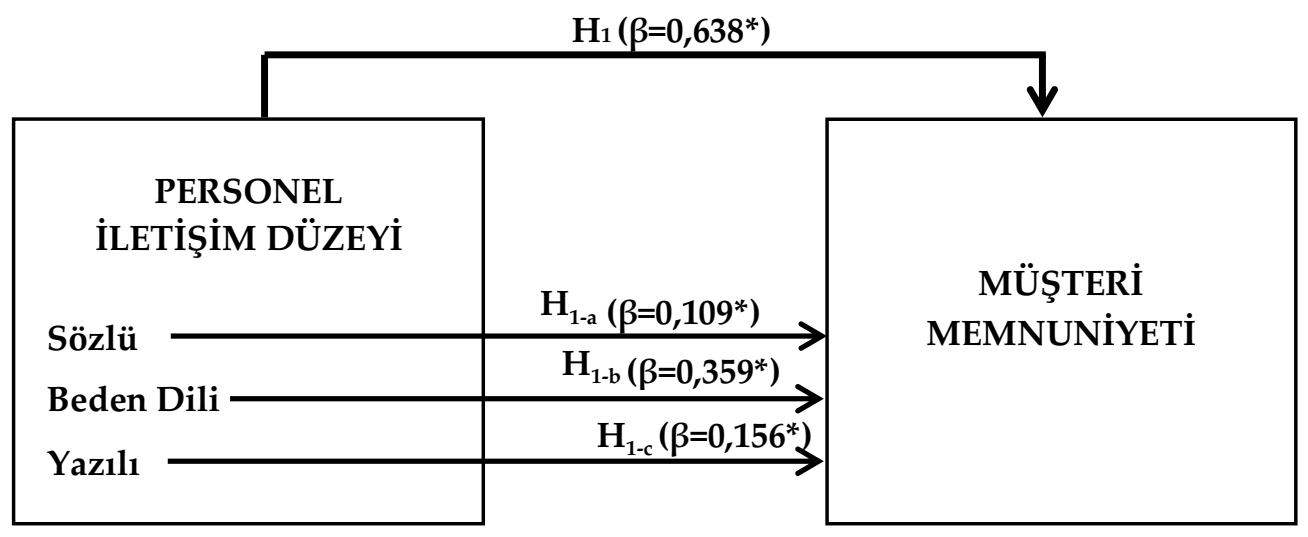

Şekil 2. Araştırma Bulgularının Model Üzerinde Gösterimi

Şekil 2'ye göre araştırma bulguları neticesinde müşterilerin personel iletişim düzeyleri algılarını; sözlü iletişimin $\beta=0,109$ ve $(\mathrm{p}=0,000, p<0,01)$ anlamlılık düzeyinde, beden dili iletişiminin $\beta=0,359$ ve $(p=0,000, p<0,01)$ anlamlılık düzeyinde ve yazılı iletişimin $\beta=0,156$ ve $(\mathrm{p}=0,000, p<0,01)$ anlamlılık düzeyinde memnuniyetlerini olumlu etkilediği saptanmıştır. Ayrıca müşterilerin personel iletişim düzeyi algılarının memnuniyetlerini $\beta=0,638$ ve $(p=0,000, p<0,01)$ anlamlılık düzeyinde olumlu etkilediği tespit edilmiştir.

\section{SONUÇ}

Ürün veya hizmet sunan tüm işletmelerde müşteri memnuniyetinin sağlanması önem arz etmektedir. Bu bağlamda emek yoğun hizmet işletmesi olan restoran işletmeleri, sürdürülebilirliğini sağlamak için müşteri beklentilerini, istek ve ihtiyaçlarını doğru anlamalıdır. Müşterileri memnun etmenin çeşitli faktörlere (estetik, tasarım, ambiyans, aydınlatma, yiyeceklerin niteliği, menü, fiyat vb.) dayandığı birçok araştırma (Andaleeb ve Conway, 2006; Akkuş ve Cengiz, 2013; Albayrak, 2014; Sabir vd., 2014; Almohaimmeed, 2017; Karakaş vd., 2017) ile tespit edilmeye çalışılmıştır.

Restoranlarda fiziksel koşulların yanı sıra çalışan personelin becerileri de müşteri memnuniyeti sağlama açısından belirgin bir etkiye sahiptir. Hizmet işletmesinde çalışan personeller ve müşteriler arasındaki etkileşimin iyi düzeyde olması müşterilerin işletmelerden memnun ayrılmasına sebep olmaktadır. Dolayısıyla personellerin müşteri memnuniyetini sağlamada nasıl bir etkiye sahip olduğunun tespit edilmesi elzemdir. Fakat bu kapsamda kısıtlı sayıda araştırmaya (Clemes vd., 2009; Çatı vd., 2010; Wu ve Mohi, 2015) rastlanmaktadır.

Restoranları ziyaret eden müşterilerin personel iletişim düzeyi algılarının memnuniyetlerine etkisinin bulunup bulunmadığını ortaya çıkarmak amaçlı bu çalışmada aşağıdaki sonuçlara ulaşılmıştır:

Araştırma kapsamında Safranbolu restoranları özelinde genel bir değerlendirme yapılacak olursa müşteri profili; cinsiyet açısından erkekler, medeni durum açısından bekarlar, eğitim durumu bakımından lisans eğitimli olanlar, yaş açısından 21-30 yaş aralığı, aylık gelir açısından 1501-2500 TL aralığı ve restorana gitme sıklığı açısından ise haftada bir kez olarak oluşmaktadır. Ayrıca müşterilerin personel iletişim düzeyi algıları; sözlü, yazılı ve beden dili, memnuniyetleri ise; ekipman ve malzeme, tasarım, aydınlatma, ambiyans ve estetik şeklinde öncelik sırasına göre şekillenmektedir. 
Yapılan bu araştırma sonuçları göstermiştir ki personel iletişim düzeyi ve alt boyutlarının (sözlü iletişim, yazılı iletişim, beden dili iletişimi) müşteri memnuniyetine olumlu yönde etkisi vardır. Araştırma sonuçlarına göre personelin iletişim düzeyinin olumlu yönde artması müşteri memnuniyetinin de artmasına sebep olmaktadır. Bu durum restoranları ziyaret eden, ürün ve hizmet satın alan müşterilerin memnun ayrılmasında sadece restoranın fiziki ortamından etkilenmediğini, bunun yanında çalışan personellerin de memnuniyet sağlamada önemli bir etken olduğunu göstermektedir. Bu kapsamda restoran yöneticilerinden ilk yapmaları gereken davranış, mevcut çalışanlarının iletişim becerilerini geliştirmesine katkı sağlamaktır. Bunun yanında işe alım sürecinde personel adaylarının iletişim becerilerini tespit ederek veya çeşitli mülakat yöntemleriyle iletişim düzeylerini ölçerek bu süreci tamamlamaları yerinde olacaktır. Ayrıca işletmelerin çalıştırdığı personeller bulunduğu bölgedeki üniversiteler veya diğer paydaşlar aracılığıyla iletişim konusunda uygulamalı eğitim seminerler ile desteklenmelidir.

$\mathrm{Bu}$ araştırmada elde edilen sonuçlar, Safranbolu ilçesinde bulunan restoranları ziyaret eden müşterilerin personel iletişim düzeyi algılarını ve memnuniyetlerini belirlemeye yönelik ölçme aracı ile sınırlıdır. Dolayısıyla uygulanan ölçme aracının farklı zaman diliminde uygulanması veya başka bölgelerde uygulanması durumunda farklı sonuçlar elde edilebilir. Bununla birlikte araştırmada personellerin iletişim beceri düzeyleri belirlenmeye çalışılmıştır. Daha sonraki yapılacak çalışmalarda personellerin kişilik özelliklerinin veya hijyen davranışlarının müşteri memnuniyeti üzerine etkisine yönelik araştırmalar yapılabilir. Ayrıca daha sonraki çalışmalarda müşteri şikayetleri veya personellerin müşterilerle iletişim zorlukları üzerine araştırmalar yapılması yeni bakış açıları oluşturabilir.

\section{KAYNAKÇA}

Akkuş, Ç. ve Cengiz, G. (2013). Beş Yıldızlı Otel Restoranları Müşteri Memnuniyeti: Erzurum İlinde Bir Araştırma. Journal of Yasar University, 8(31), 5229-5252.

Albayrak, A. (2014). Müşterilerin Restoran Seçimlerini Etkileyen Faktörler: İstanbul Örneği. Anatolia: Turizm Araştırmaları Dergisi, 25(2), 190-201.

Almohaimmeed, B. M. A. (2017). Restaurant Quality and Customer Satisfaction. International Review of Management and Marketing, 7(3), 42-49.

Andaleeb, S. S. and Conway, C. (2006). Customer Satisfaction in the Restaurant Industry: An Examination of the Transaction-Specific Model. Journal of Services Marketing, 20(1), 3-11.

Ayaz, N. ve Yalı, S. (2017). Kültürel turistlerin seyahat tercihleri ve yiyecek-içecek beklentileri: Safranbolu örneği. Türk Turizm Araştırmaları Dergisi, 1(1), 43-61.

Bucak, T. ve Turan, Ö. (2016). Restoranlarda Hizmet Kalitesinin Misafir Memnuniyetine Etkisi: Çanakkale Merkezinde Bir Araştırma. The Journal of Academic Social Science Studies, (49), 287-304.

Clemes, M. D., Wu, J. H., Hu, B. and Gan, C. (2009). An Empirical Study of Behavioral Intentions in the Taiwan Hotel Industry. Innovative Marketing, 5(3), 30-50.

Countryman, C. C. and Jang, S. (2006). The Effects of Atmospheric Elements on Customer Impression: The Case of Hotel Lobbies. International Journal of Contemporary Hospitality Management, 18(7), 534-545.

Çatı, K., Koçoğlu, C. M. ve Gelibolu, L. (2010). Müşteri Beklentileri ile Müşteri Sadakati Arasındaki İlişki: Beş Yıldızlı Bir Otel Örneği. Ç.Ü. Sosyal Bilimler Enstitüsü Dergisi, 19(1), 429-446. 
Çıkmaz, E. (2013). Otel İşletmelerinde Çalışan Personelin Sahip Olduğu İletişim Becerisinin Yükseköğretim Mezunu Müşteriler Tarafından Değerlendirilmesine Yönelik Gaziantep'te Bir Uygulama. Yayınlanmamış Yüksek Lisans Tezi, Hasan Kalyoncu Üniversitesi, Sosyal Bilimler Enstitüsü, Gaziantep.

Erkuş, A. ve Günlü, E. (2009). İletişim Tarzının ve Sözsüz İletişim Düzeyinin Çalışanların İş Performansına Etkisi: Beş Yıldızlı Otel İşletmelerinde Bir Araştırma. Anatolia: Turizm Araştırmaları Dergisi, 20(1), 7-24.

Farrell, A. M., Souchon, A. L. and Geoffrey R. (2001). Service Encounter Conceptualisation: Employees' Service Behaviours and Customers' Service Quality Perceptions. Journal of Marketing Management, 17(5), 577-593.

Karakaş, A., Bilgin, Y. ve Kıngır, S. (2017). Restoran İşletmelerinde Müşteri Memnuniyetinin Müşteri Sadakatine Etkisi: Amasra' da Faaliyet Gösteren Balık Restoranları Üzerine Bir Araştırma. B. Zengin ve O. Özer (Ed.), 4th International Congress of Tourism \& Management Researches içinde (s.600-619). Girne.

Kumar, I., Garg, R. and Rahman, Z. (2010). Influence of Retail Atmospherics on Customer Value in An Emerging Market. Great Lakes Herald, 4(1), 1-13.

Olcay, A., Giritlioğlu, İ. ve Çıkmaz, E. (2014). Otel İşletmelerinde Çalışan Personelin İletişim Yeterlilik Düzeyi: Gaziantep Bölgesinde Bir Araştırma. İşletme Araştırmaları Dergisi, 6(1), 385-403.

Petzer, D. and Mackay, N. (2014). Dining Atmospherics and Food and Service Quality as Predictors of Customer Satisfaction at Sit-Down Restaurants. African Journal of Hospitality, Tourism and Leisure, 3(2), 1-14.

Quin, H. and Prybutok, V. R. (2009). Service Quality, Customer Satisfaction, and Behavioral Intentions in Fast-Food Restaurants. International Journal of Quality and Service Sciences, 1(1), 7895.

Sabir, R. İ., Ghafoor, O., Hafeez, İ, Akhtar, N. and Rehman, A. U. (2014). Factors Affecting Customers Satisfaction in Restaurants Industry in Pakistan. International Review of Management and Business Research, 3(2), 869-876.

Ural, A. ve Kılıç, İ. (2006). Bilimsel Araştırma Süreci ve SPSS ile Veri Analizi. Ankara: Detay Yayincilik.

Ünal, S., Akkuş, G. ve Akkuş, Ç. (2014). Yiyecek İçecek İşletmelerinde Atmosfer, Duygu, Memnuniyet ve Davranışsal Sadakat İlişkisi. Gazi Üniversitesi Turizm Fakültesi Dergisi, (1), 23-49.

Wu, J. H. and Mohi, Z. (2015). Assessment of Service Quality in the Fast-Food Restaurant. Journal of Foodservice Business Research, 18(4), 358-388. 